\title{
The Effect of Talent Management, Knowledge Management and Work Culture on the Performance in the Survey Unit Centre of Hydrography and Oceanography Indonesia Naval (Pushidrosal)
}

\author{
Dian Amrainy and Lenny Christina Nawangsari
}

\section{ABSTRACT}

The purpose of this study was to determine whether talent management, knowledge management and work culture have a significant influence on organizational performance. The research method used is explanatory research conducted quantitatively. In order to obtain complete and relevant data, in addition to primary data in the form of surveys, researchers also use secondary data. The author took a sample of 100 members of the PT $X$ survey unit. Data were collected using a questionnaire in the form of a list of questions. The data analysis method used is Partial Least Square (PLS). The results of this study indicate that talent management does not have a significant effect on organization performance. Knowledge management has a positive and significant effect on organization performance. Work Culture has no significant effect on organization performance. Talent management, knowledge management and work culture together have a significant effect on organization performance. Suggestions given in this research are that the organization must consistently and continuously provide understanding to personnel, in order to use the opportunities given by the organization to improve competence and qualifications through education and training. Personnel must also ensure that improvements in the quality of work results come from education and training. By improving talent management practices, knowledge management and work culture it is hoped that it can improve organizational performance and achieve company goals.

Keywords: Talent Management, Knowledge Management, work culture, organization performance.
Submitted : January 31, 2021

Published : March 11, 2021

ISSN: 2507-1076

DOI: $10.24018 / \mathrm{ejbmr} .2021 .6 .2 .723$

Dian Amrainy*

Magister Management, Mercu Buana University, Jakarta, Indonesia.

(e-mail: dianamrainy_70@yahoo.com)

Lenny Christina Nawangsari

Magister Management, Mercu Buana

University, Jakarta, Indonesia.

*Corresponding Author

\section{INTRODUCTION}

The 21 st century is marked by the development of the technological era and globalization that requires organizations to carry out dynamical change. Various changes were made as a logical consequence of the rapid development of science and technology along with globalization in all aspects of life, including the revolution in information and communication technology. The Naval Hydrographic and Oceanography Center (Pushidrosal) as the Main Command (Kotama) of the Navy's Guidance in the field of conducting Hydro-Oceanographic Surveys and Mapping (Surta Hidros) in achieving Pushidrosal's duties and functions as a national hydrographic institution and still having a chain of command with the Indonesian Navy, must be able to respond to changes in science and technology and globalization through optimal use of organizational resources.

Organizational performance is an accumulation of the performance of personnel who work in the organization. The success or failure of the performance achieved by an organization is influenced by the level of performance of the employees, both individually and in groups. With the assumption that the better the employee's performance, the better the organizational performance is expected [1]. Pushidrosal organizational performance shows the ability of them to carry out its assigned tasks as well as possible in order to achieve the vision and mission that is outlined in the goals and objectives of the organization. The performance achieved by the Pushidrosal organization must be adjusted to the vision and mission of quality and quantity as a form of the responsibility of the Pushidrosal organization as a Government Agency in the field of public services in providing data and information in the field of Surta Hidros. A good organization is an organization that manages to achieve its vision, mission and goals. The success of the organization is certainly supported by the maximum performance of the organization's crew. The era of Bureaucratic Reform is a major change in paradigm and governance to achieve "good and clean governance" regarding aspects of government management with the goal 
of clean, accountable, and high-performance governance and the implementation of good and quality public services.

From the data issued by "Permenpan RB" number 11 of 2015 , it is known that the target of achieving organizational performance in all government institutions including Pushidrosal has not been achieved. The implementation of reforms in the period of 2010-2014 still leaves various challenges ahead which must be improved gradually and continuously. Several strategic problems that still need to be fixed through the implementation of bureaucratic reform include: The bureaucracy is not completely clean and accountable, the bureaucracy is not yet effective and efficient public services still do not have the expected quality.

In the framework of Bureaucratic Reform in order to improve these three strategic problems, the government, in this case the Ministry of State Apparatus Empowerment and Bureaucratic Reform, implements the program known as "8 Areas of Change" as stipulated in the Regulation of the Minister of State Apparatus Empowerment and Bureaucratic Reform of the Republic of Indonesia Number 11 of 2015 concerning Road Map of Bureaucratic Reform 2015-2019 [2], which includes "8 Areas of Change" which is: Change Management, Arrangement of Legislation, Regulation and Strengthening of Organizations, Organizational Structuring, Structuring HR Management Systems, Strengthening Supervision, Strengthening Performance Accountability and Enhancing Quality of Public Services.

The "8 Areas of Change" in order to improve Organizational Performance in all governmental circles stipulated by the Ministry of Administrative Reform and Bureaucratic Reform can be divided into several categories that will become research subjects, namely, quality improvement in the field of talent management, knowledge management and work culture.

Pushidrosal has implemented these "8 Areas of Change" in practice since 2019, and the results of the assessment for 2020 have not been determined by "Menpan RB". Therefore, the author uses the data from 2010 to 2015 which illustrates that there is still a gap for the results achieved compared to the targets that have been set. In addition, the author was interested in the "8 Areas of Change" strategy that must be carried out by all government institutions in order to improve their performance, in which there are elements of increased talent management, knowledge management, and work culture that the author chooses to be the independent variables and their influence on organizational performance as the dependent variable in this study.

\section{LITERATURE REVIEW AND HYPOTHESIS DEVELOPMENT}

\section{A. The Effect of Talent Management on Organization Performance}

Talent management has a real influence or impact on performance. Talent management should be maintained and enhanced through education, training, and career development [3]. Talent management is positively related to organizational performance. Organizations to improve talent and performance management through enhanced learning and development initiatives. Baket management also has a significant partial effect on organizational performance [4].
Based on previous research and the theory used as a research reference, the first hypothesis can be built,

H1: Talent Management affects the Performance of Organization.

\section{B. Influence of Knowledge Management on Organization Performance}

Knowledge to be the most important factor of production besides organizational resources. Knowledge is a unique organizational resource and cannot be replicated. The conceptual model of knowledge management and organizational productivity is a useful starting point for gaining deeper insight into the influence of organizational knowledge management on organizational competitiveness and innovation [5].

Knowledge management has a positive influence on organizational performance. Knowledge management applications include knowledge mapping, human resource development, knowledge sharing, and work cycles [6].

Knowledge management has significantly and positively effect the organizational performance. Knowledge management will affect organizational performance, where the higher the level of knowledge management application, the higher the organizational performance [7].

Based on previous research and the theory used as a research reference, a second hypothesis can be built,

$\mathrm{H} 2$ : Knowledge management affects the Performance Organization.

\section{The Influence of Work Culture on Organizational Performance}

Work culture is a form or a way of individuals to actualize themselves in organizations. Work culture is very important in the world of work to improve the highly qualified quality of one's work. This individual can become a superior and beneficial employee or worker for the company that employs him. The organization must have superior or competent people in every field in order to maximize organizational performance.

Organizational culture has a significant positive effect on organizational performance [8]. Work culture is derived from organizational culture which is a pattern of basic assumptions that are found, created, or developed by a certain group with the intention that organizations learn to overcome or cope with problems that arise as a result of external adaptation and internal integration that are already running with the new one, as the correct way to understand, think, and feel in relation to these problems. Work culture as a derivative of organizational culture in the form of organizational learning to overcome or overcome problems has an impact on organizational performance [9].

The form of work culture is productivity, which is in the form of work behavior that is reflected in, among others, hard work, resilience, discipline, productivity, responsibility, motivation, benefits, creative, dynamic, consequent, responsive, independent, be better, and others [10]. Work culture has a positive and significant influence on employee performance. Work culture must be enforced in an organization. Work culture is the key to the success of an organization in achieving organizational goals [11].

Based on previous research and the theory used as a research reference, a third hypothesis can be built: 


\section{H3: Work culture affects Organization Performance.}

D. The Simultaneous Influence of Talent Management, Knowledge Management, and Work Culture on Organization Performance

Employee performance and organizational performance are very closely related. The achievement of organizational goals cannot be separated from the resources owned by the organization which are run by employees who play an active role as actors in achieving the organizational goals. Basically, organizational performance is the responsibility of every individual who works in the organization. If in the organization every individual works well, performed, enthusiastic, and gives their best contribution to the organization, the overall organizational performance will be good. Thus, organizational performance is a reflection of individual performance [12].

Employee performance appraisal and organizational performance is a performance appraisal system that helps to generate feedback, review, and estimate the effectiveness of employee performance. Individual performance appraisal is an important part of human resource management's contribution to the organization [13].

The achievement of organizational goals cannot be separated from the resources owned by the organization which are run by employees who play an active role as actors in achieving organizational goals. Individual performance works well, performed, enthusiastic and gives their best contribution to the organization so that the overall organizational performance will be good. Work culture aims to change existing behavior in order to improve company performance. The results of this study support the case [14].

Based on previous research and the theory used as a research reference, a fourth hypothesis can be built.

H4: Talent Management, Knowledge Management, and Work Culture simultaneously influence Organization Performance.

\section{RESEARCH METHODOLOGY}

The research design used in this study was an explanatory research design that was carried out quantitatively. The research method used to determine the regression of the independent variable $(\mathrm{X})$, with the dependent variable $(\mathrm{Y})$, is called regression research which aims to find whether or not there is an effect between variables, and if it was there, how much influence it has and whether it means or not. Based on the Slovin formula, the required sample size is 100 people because the partial least square analysis method has a minimum sample requirement of 30 respondents [15].

In this study, the independent variables used were talent management, knowledge management and work culture; and the dependent variable used is organizational performance. Measurement of the variable indicators of this study uses a Likert scale [16], by compiling a statement where each item is given a score range between (1); strongly disagree, up to (5); strongly agree. This quantitative data is obtained from distributing questionnaires to employees who work at PT. X Indonesia, obtained through interviews and conducting field observations as well as distributing questionnaires to employees.
The data analysis in this study used the partial least square method assisted by SmartPLS software. Partial Least Square can be used on any type of data scale (nominal, ordinal, interval and ratio) as well as more flexible assumption requirements [17]. Partial Least Square is also used to measure the relationship of each indicator with its construct [18]. Then, in partial least square a bootstrapping test can be carried out on the structural model that has the nature of the outer model and the inner model [19].

\section{RESEARCH RESULT AND DISCUSSION}

Characteristics of respondents based on gender are, 100 male respondents and 0 female respondents. Based on these data, the largest number of respondents is male. While the characteristics based on age less than 20 years 0 respondents, ages 21 to 25 years totaled 25 respondents, ages 26 to 30 years totaled 27 respondents, ages 31 years to 35 years totaled 30 respondents, and ages over 36 years totaled 18 respondents. Based on age, the characteristics of the most respondents were 31 to 35 years old, namely 30 respondents.

Karakteristik responden selanjutnya adalah berdasarkan pangkat, hasil kuesioner menunjukan bahwa responden dengan pangkat Perwira berjumlah 40 responden, pangkat Bintara berjumlah 50 responden, dan pangkat Tamtama berjumlah 10 responden. Latar belakang pangkat Bintara memiliki jumlah responden paling banyak yaitu 50 responden.

The characteristics of the next respondent are based on length of work, the results of the questionnaire show that 47 respondents had worked for 0-3 years, 36 respondents had worked for 3-6 years, 10 had worked for 6-10 years, and 7 had worked for longer than 10 years.

\section{A. Validity Test}

Evaluation of measurement models in partial least squares is an evaluation of the relationship between constructs and indicators. This evaluation includes two stages, namely evaluation of convergent validity and discriminant validity. Convergent validity can be evaluated in three stages, namely, the validity indicator, construct reliability, and the average variance extracted value. Convergent validity of the measurement model with reflexive indicators can be seen from the correlation between the item/ indicator score and the construct score. Indicators can be said to be reliable or acceptable if they have a correlation value above 0.50 .

The output results between the indicators and their constructs still have invalid indicators with a factor loading value below 0.5 , if the invalid indicators are not removed, it can reduce the level of validation of the final results. Based on the results of the outer loadings on Fig. 2, the original sample number of each indicator has shown a value of more than 0.5 , it can be said that all indicators have met the validity requirements. 


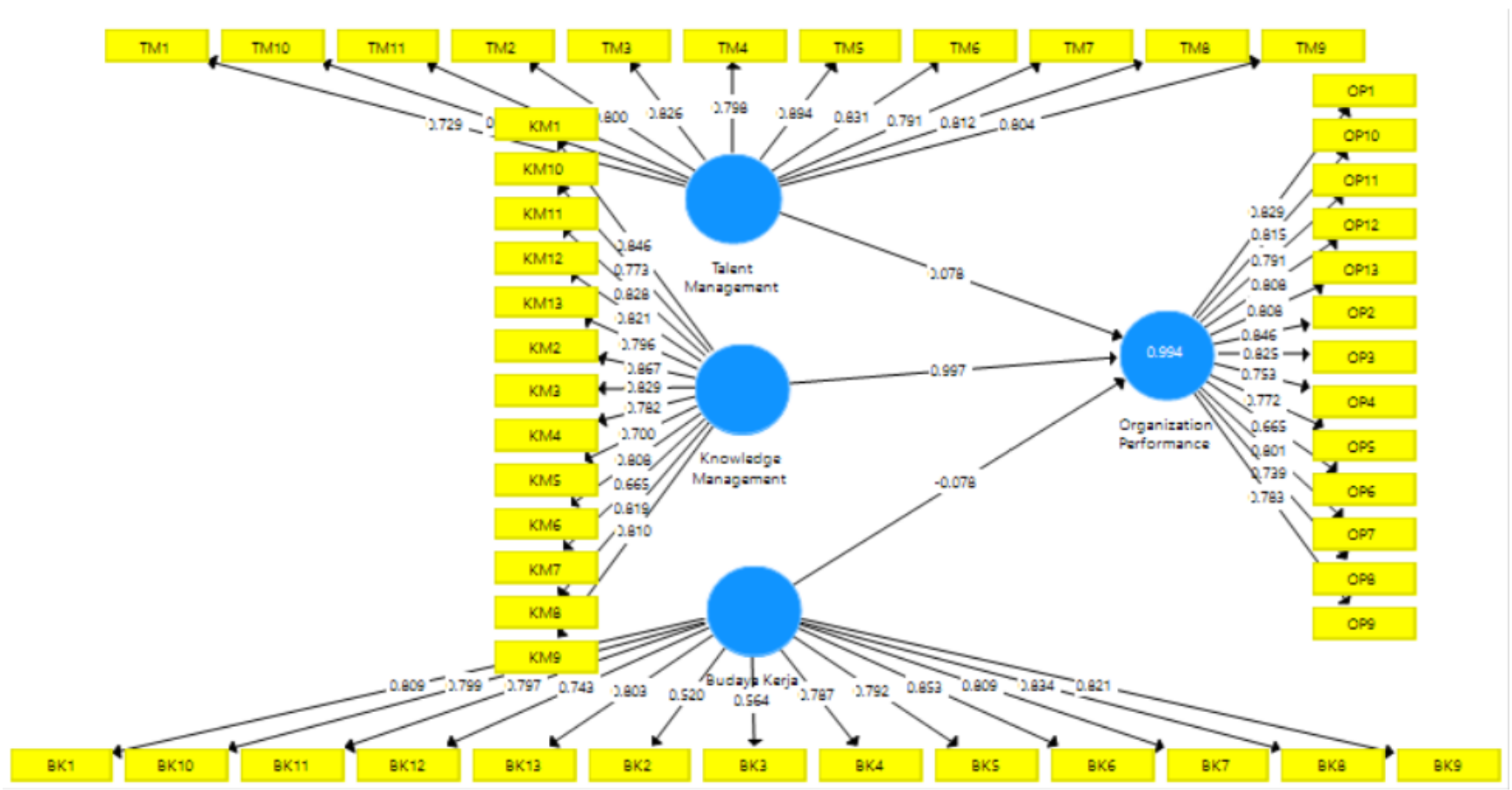

Fig. 1. Outer loadings (not yet valid).

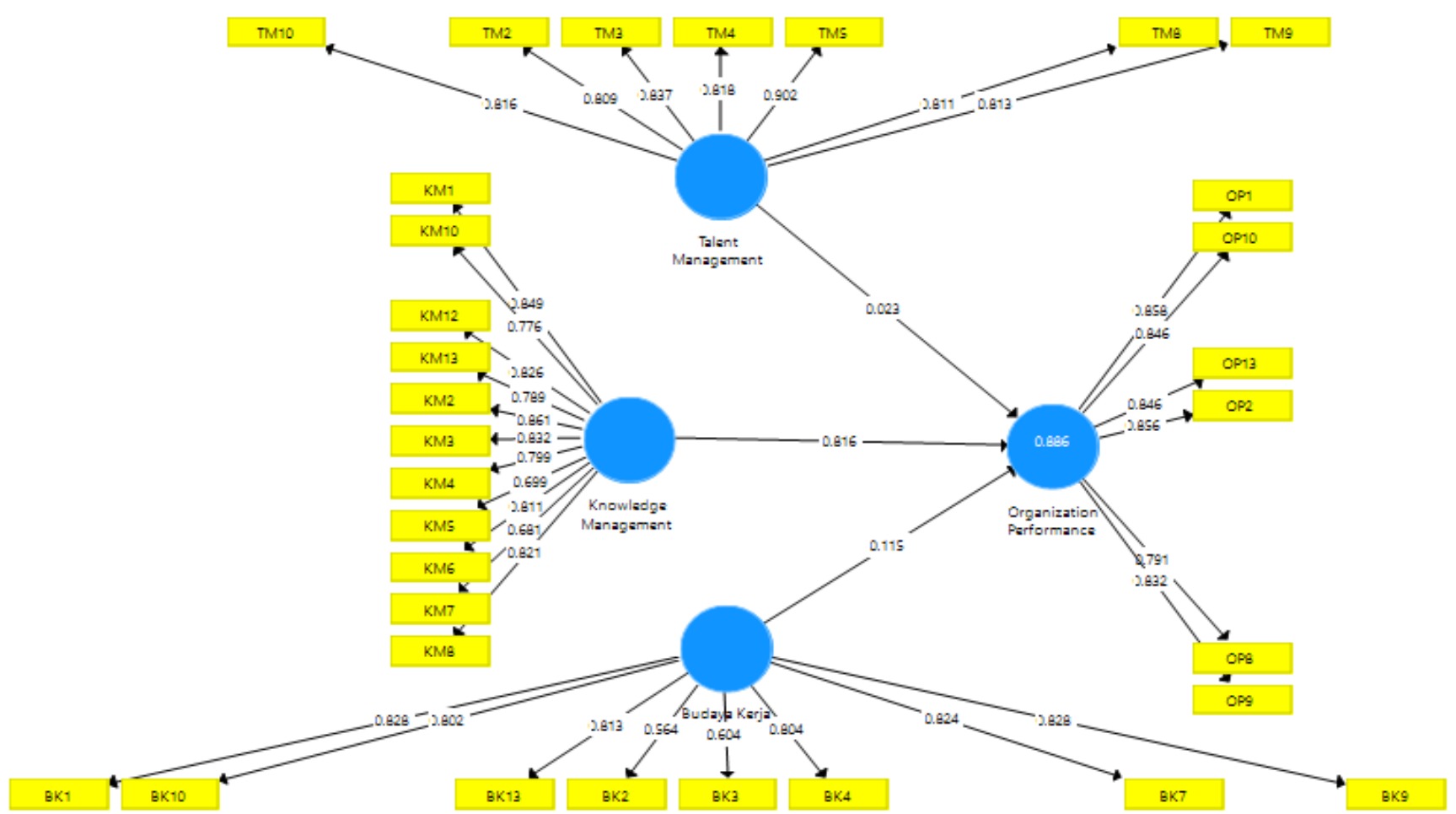

Fig. 2. Outer loadings (valid).

Then the correlation between the Talent Management construct and the indicator is higher than the correlation between the Talent Management indicator and other constructs (Knowledge Management, Work Culture and Organization Performance). The correlation of the Knowledge Management construct with its indicators is higher than the correlation of Knowledge Management indicators with other constructs (Talent Management, Work Culture and Organization Performance). The correlation of the Work Culture construct with the indicator is higher than the correlation of the Work Culture indicator with other constructs (Talent Management, Knowledge Management, and Organization Performance). The correlation of the Organization Performance construct with its indicators is higher than the correlation of Organization Performance indicators with other constructs (Talent Management, Knowledge Management, and Work Culture). So, it can be said that all the constructs in the estimated model meet the criteria for discriminant validity. 
TABLE I: CROSS LOADINGS (VALID) Hasil PENGUJIAN DISCRIMINANT VALIDITY (CROSS LOADINGS) SETELAH

\begin{tabular}{|c|c|c|c|c|}
\hline & $\begin{array}{c}\text { Talent } \\
\text { Management }\end{array}$ & $\begin{array}{c}\text { MODIFIKASI } \\
\text { Knowledge } \\
\text { Management }\end{array}$ & $\begin{array}{c}\text { Budaya } \\
\text { Kerja }\end{array}$ & $\begin{array}{l}\text { Organization } \\
\text { Performance }\end{array}$ \\
\hline TM2 & 0,809 & 0,735 & 0,766 & 0,713 \\
\hline TM3 & 0,837 & 0,713 & 0,787 & 0,698 \\
\hline TM4 & 0,818 & 0,751 & 0,755 & 0,690 \\
\hline TM5 & 0,902 & 0,790 & 0,820 & 0,776 \\
\hline TM8 & 0,811 & 0,771 & 0.787 & 0,735 \\
\hline TM9 & 0,813 & 0,682 & 0,759 & 0,661 \\
\hline TM10 & 0,816 & 0,738 & 0,753 & 0,708 \\
\hline KM1 & 0,739 & 0,849 & 0,799 & 0,816 \\
\hline KM2 & 0,782 & 0,861 & 0,792 & 0,832 \\
\hline KM3 & 0,785 & 0,832 & 0,772 & 0,801 \\
\hline KM4 & 0,698 & 0,799 & 0,707 & 0,675 \\
\hline KM5 & 0,535 & 0,699 & 0,575 & 0,600 \\
\hline KM6 & 0,701 & 0,811 & 0,722 & 0,719 \\
\hline KM7 & 0,601 & 0,681 & 0,595 & 0,680 \\
\hline KM8 & 0,734 & 0,821 & 0,705 & 0,790 \\
\hline KM10 & 0,706 & 0,776 & 0,676 & 0,760 \\
\hline KM12 & 0,764 & 0,826 & 0,762 & 0,799 \\
\hline KM13 & 0,736 & 0,789 & 0.713 & 0,710 \\
\hline BK1 & 0,741 & 0,791 & 0,828 & 0,781 \\
\hline BK2 & 0,453 & 0,386 & 0,564 & 0,435 \\
\hline BK3 & 0,549 & 0,502 & 0,604 & 0,494 \\
\hline BK4 & 0,761 & 0,664 & 0,804 & 0,640 \\
\hline BK7 & 0,793 & 0,759 & 0,824 & 0,716 \\
\hline BK9 & 0,790 & 0,769 & 0,828 & 0,736 \\
\hline BK10 & 0,778 & 0,698 & 0,802 & 0,650 \\
\hline BK13 & 0,775 & 0,791 & 0,813 & 0,762 \\
\hline OP1 & 0,733 & 0,808 & 0,726 & 0,858 \\
\hline OP2 & 0,761 & 0,840 & 0,767 & 0,856 \\
\hline OP8 & 0,662 & 0,719 & 0,676 & 0,791 \\
\hline OP9 & 0,705 & 0,782 & 0,663 & 0,832 \\
\hline OP10 & 0,712 & 0,773 & 0,726 & 0,846 \\
\hline OP13 & 0,741 & 0,797 & 0,791 & 0,846 \\
\hline
\end{tabular}

Sumber: Output PLS.

\section{B. Reliability Test}

The construct reliability test is carried out by measuring two criteria, namely composite reliability and Cronbach alpha from the indicator block that measures the construct. The construct is declared reliable if the composite reliability and Cronbach alpha values are above 0.70 .

\begin{tabular}{ccc}
\multicolumn{3}{c}{ TABLE II: COMPOSITE RELIABILITY } \\
\hline Variabel & $\begin{array}{c}\text { Composite } \\
\text { Reliability }\end{array}$ & Ket \\
\hline Talent Management & 0,939 & Reliabel \\
Knowledge Management & 0,950 & Reliabel \\
Budaya Kerja & 0,917 & Reliabel \\
Organization Performance & 0,934 & Reliabel \\
\hline Sumber: Output PLS. & \\
TABLE III: CRONBACHS ALPHA & \\
\hline Variabel & Cronbach's Alpha & Ket \\
\hline Talent Management & 0,925 & Reliabel \\
Knowledge Management & 0,942 & Reliabel \\
Budaya Kerja & 0,896 & Reliabel \\
Organization Performance & 0,915 & Reliabel \\
\hline Sumber: Output PLS. & &
\end{tabular}

Based on Tables II and III, it can be seen that the constructs of Talent Management, Knowledge Management, Work
Culture and Organization Performance have a value above 0.6. So, it can be concluded that all constructs are declared reliable.

\section{Structural Model Test}

The structural model indicates that the model for the Organization Performance variable can be said to be strong because it has a value above 0.67 . The model of the influence of independent latent variables (talent management, knowledge management and work culture) on organization performance gives an R-square value of 0.882 which can be interpreted that the variability of the organization performance construct can be explained by the variability of the constructs of talent management, knowledge management and work culture of $88.2 \%$ while $11.8 \%$ is explained by other variables outside the study.

\begin{tabular}{|c|c|c|}
\hline & T-Statistics & T-Table \\
\hline $\begin{array}{c}\text { Talent Management } \rightarrow \text { Organization } \\
\text { Performance }\end{array}$ & 0,214 & 1,66 \\
\hline $\begin{array}{c}\text { Knowledge Management } \rightarrow \text { Organization } \\
\text { Performance }\end{array}$ & 11,62 & 1,66 \\
\hline $\begin{array}{c}\text { Budaya Kerja } \rightarrow \text { Organization } \\
\text { Performance }\end{array}$ & 1,208 & 1,66 \\
\hline
\end{tabular}

Sumber: Output PLS.

Table IV is used to determine the magnitude of the direct influence between constructs by looking at the original sample for the magnitude of the influence and the T-statistic value that is greater than 1.66 , it can be said that the construct affects other constructs, so it can be seen whether the relationship of each variable has an effect or not. So, based on the results of data processing it can be concluded that only Knowledge Management variables have a relationship with Organization Performance because the T-Static results are greater than T-Table.

\section{Hypotesis Test}

Based on Table $\mathrm{V}$, what is used to determine the magnitude of the influence between constructs is to look at the original sample column. The influence between Talent Management and Organizational Performance is positive because the T-statistic value of 0.214 is smaller than the Ttable 1.66 and the effect is weak because the original sample value is only $2.3 \%$. The influence between Knowledge Management and Organizational Performance is positive because the T-statistic value is 20.066 greater than the Ttable 1.66 and the effect is strong because the original sample value reaches $81.6 \%$. The influence between Work Culture and Organizational Performance is positive because the Tstatistic value of 1.208 is smaller than the T-table 1.66 and the effect is weak because the original sample value is only $11.5 \%$.

\begin{tabular}{ccccccc} 
& & & \\
& TABEL V: HYPOTESIS TEST & & P- & T- & & Keterangan \\
Values & Sample & Standard & Deviation & Statistics & Valinal \\
\hline Talent Management $\rightarrow$ Organization Performance & 0,023 & 0,106 & 0,214 & 0,831 & Positif tidak signifikan \\
Knowledge Management $\rightarrow$ Organization Performance & 0,816 & 0,070 & 11,62 & 0,000 & Positif signifikan \\
Budaya Kerja $\rightarrow$ Organization Performance & 0,115 & 0,095 & 1,208 & 0,228 & Positif tidak signifikan \\
\hline
\end{tabular}

Sumber: Output PLS. 
Based on Table $\mathrm{V}$, information can be obtained that the influence of Talent Management on Organizational performance is positive and insignificant, it can be seen through the t-statistic value of 0.214 which is smaller than the t-table value of 1.66 and also through the coefficient value in the original sample column of 0.023 . Therefore, hypothesis 1 which states the influence of Talent Management on Organizational performance, is rejected. The influence of Knowledge Management on Organization Performance is positive and significant, it can be seen through the t-statistic value of 11.62 which is greater than the t-table value of 1.66 and also through the coefficient value in the original sample column of $81.6 \%$. Therefore, hypothesis 2 which states the influence of Knowledge Management on Organizational Performance is accepted. The influence of Work Culture on Organization Performance is negative and significant that can be seen through the t-statistic value of 1.208 which is smaller than the t-table value of 1.66 and also through the coefficient value in the original sample column of $11.5 \%$. Therefore, hypothesis 3 which states the influence of Work Culture on Organizational Performance is rejected.

Based on the bootstrapping test, the indicator in the Talent Management variable with the lowest t-statistic value is the TM2 indicator (Systematics for Internal Training (LDD) is very supportive of the job). If this indicator is improved, it will make the Talent Management variable stronger. In the Knowledge Management variable with the lowest t-statistic value is the KM5 indicator (personnel have the same opportunity to attend work-related seminars / workshops). If this indicator is improved, it will make the Knowledge Management variable stronger. Meanwhile, the Work Culture variable with the lowest t-statistic value is the BK2 indicator (Each personnel has understood individual responsibilities in completing work). If this indicator is improved, it will make the Work Culture variable stronger.

\section{CONCLUSIONS}

The conclusions that have been drawn from a series of tests show that Talent Management has an effect on Organizational Performance with insignificant effect. Thus, Pushidrosal Organizational Performance cannot be directly influenced by Talent Management in the company. Knowledge Management has an influence on Organizational Performance with a positive effect. Thus, Pushidrosal Organizational Performance can be directly influenced by the Knowledge Management in the company. Work Culture has an influence on Organizational Performance with insignificant influence characteristics. Thus, Pushidrosal Organizational Performance cannot be directly influenced by the existing Work Culture within the company.

Based on the results of the analysis and discussion in the previous chapter and the conclusions that have been made, the proposed suggestion is that the indicator which has the lowest T-statistic value of the Talent Management variable is a statement regarding the Systematics of the Implementation of Internal Training (LDD) which strongly supports the work. It can be concluded that there are still personnel who think that the systematics of implementing In-Service Training (LDD) does not support work. On the job training which is carried out in a good systematic manner is very supportive of the job because personnel can do direct practice in connection with the tasks to be performed. However, education / training will be much more important because OJT is only a complement to the education / training provided. In the future, Pushidrosal should make policies around better and more flexible education and provide more transparent information about the importance of education for employees, so as to increase employee interest in participating in the education program. Employee participation in educational programs will open career paths for these employees and open up opportunities for faster promotions.

Based on the results of the indicator questionnaire which has the lowest T-statistic value of the Knowledge Management variable, it is a statement that personnel have the same opportunity to attend work-related seminars / workshops. It can be concluded that there are still some personnel who disagree and hesitate to state that personnel have the same opportunity to attend work-related seminars / workshops. Seminars / workshops are more often attended by officers, both internal and external seminars / workshops held at home / abroad. In the future, Pushidrosal should create more seminar / workshop programs for all levels. With the existence of seminars / workshops, besides adding to discourse, it can be used as a means of education and a means of refreshing for personnel who regularly work every day.

Based on the results of the questionnaire, the indicator which has the lowest T-statistic value of the Work Culture variable is a statement that each personnel understand individual responsibility in completing work. It can be concluded that there are still personalities who do not understand individual responsibility in completing work. Personnel lack of understanding of job responsibilities because personnel understanding is limited to work. Incomplete understanding of the principles of the method and the achievement of work results. To create a better work culture apart from creating a conducive work atmosphere and increasing cooperation between personnel in completing every job.

\section{REFERENCES}

[1] Robbins, P, Stephen \& Coutler, Mary. (2016). Human Resources Management. Edisi 16. Jilid 1. Jakarta: Salemba Empat.

[2] Peraturan Menteri Pendayagunaan Aparatur Negara dan Reformasi Birokrasi Republik Indonesia Nomor 11 tahun 2015.

[3] Fatmasari, 2017, Pengaruh Talent Management Dan Self Efficacy Terhadap Kinerja Karyawan Distributor Alat Berat, Jurnal Bisnis Darmajaya, Vol.03. No.02.

[4] Puja Sareen dan Shikha Mishra, 2016, A Study of Talent Management and Its Impact on Performance of Organizations, IOSR Journal of Business and Management (IOSR-JBM), Volume 18, Issue 12.

[5] Fatemeh Torabia dan Jamal El-Denb, 2017, The impact of Knowledge Management on Organizational Productivity: A Case Study on Koosar Bank of Iran, 4th Information Systems International Conference 2017, ISICO 2017, 6-8 November 2017, Bali, Indonesia.

[6] Jelena Rašula, Vesna Bosilj Vukšić dan Mojca Indihar Štemberger, 2012, The Impact of Knowledge Management on Organisational Performance, Economic and Business Review.

[7] Veby Andria dan Erlin Trisyulianti, 2011, Implementasi Manajemen Pengetahuan dan Dampaknya terhadap Kinerja Organisasi pada PT Telekomunikasi Indonesia, Tbk Jurnal Manajemen dan Organisasi Vol II, No. 2.

[8] Soedjono, 2005, Pengaruh Budaya Organisasi Terhadap Kinerja Organisasi dan Kepuasan Kerja Karyawan pada Terminal Penumpang Umum di Surabaya, Jurnal Manajemen \& Kewirausahaan, Vol. 7, No. 1 . 
[9] Riani, Asri Laksmi. 2011. Budaya Organisasi. Edisi Pertama. Cetakan Pertama. Graha Ilmu. Yogyakarta.

[10] Ndraha, Taliziduhu. 2002. Pengantar Teori Pengembangan Sumber Daya Manusia. Rineka Cipta. Jakarta.

[11] Desi Rosiana Sari, Robin Jonathan dan Imam Nazarudin Latif, Pengaruh Budaya Kerja Terhadap Kinerja Pegawai Pada Badan Kesatuan Bangsa Dan Politik Kabupaten Kutai Timur, http://ejurnal.untag-

smd.ac.id/index.php/EKM/article/viewFile/1840/pdf_310, diunduh fg tanggal 21 April 2020.

[12] Pasolong, Harbani. 2010. Teori Administrasi Publik, Alfabeta, Bandung.

[13] Obiekwe, Onyebuchi dan Ejo-Orusa, Henry, 2019, Impact of Employee Performance Appraisal on Performance of Business Organizations: A Theoretical Review, EPRA International Journal of Economic and Business Review -Peer Reviewed Journal.

[14] Silvia, I Wayan Bagia dan Wayan Cipta, 2016, Pengaruh Kompetensi Dan Budaya Kerja Terhadap Kinerja Karyawan, e-Journal Bisma Universitas Pendidikan Ganesha Jurusan Manajemen.

[15] Abdillah \& Jogiyanto, 2015). Partial Least Square (PLS) Alternatif Structural Equation Modeling (SEM) dalam Penelitian Bisnis. Yogyakarta: Andi.

[16] Sekaran U., \& Bougie, R. 2010), Research Methods for Business: A Skill Building Approach. 5th Edition. New Jersey: John Wiley and Sons, Inc.

[17] Götz, O., Liehr-Gobbers K., \& Krafft, M., (2010). Evaluation of Structural equation models using the partial least square (PLS) approach in Handbook of Partial least squares (pp. 691-711). Berlin: Springer Berlin Heidelberg. 